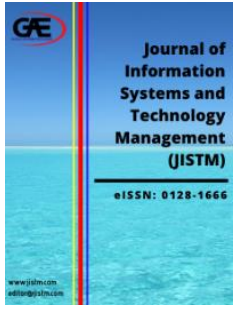

\author{
JOURNAL OF INFORMATION \\ SYSTEM AND TECHNOLOGY \\ MANAGEMENT (JISTM) \\ WWW.jistm.com
}

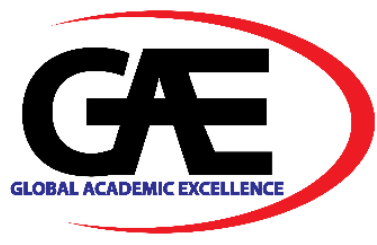

\title{
SMART LIVING IMPLEMENTATION IN MALAYSIA: A PRELIMINARY OVERVIEW
}

\author{
Koh Fung Chieng ${ }^{1 *}$, Fara Diva Mustapa ${ }^{2}$ \\ 1 Department of Quantity Surveying, Universiti Teknologi Malaysia, Malaysia \\ Email: fckoh4@graduate.utm.my \\ 2 Department of Quantity Surveying, Universiti Teknologi Malaysia, Malaysia \\ Email: faradiva@utm.my \\ Corresponding Author
}

\section{Article Info:}

Article history:

Received date: 01.10 .2021

Revised date: 01.11.2021

Accepted date: 20.11 .2021

Published date: 01.12.2021

\section{To cite this document:}

Koh, F. C., \& Mustapa, F. D. (2021). Smart Living Implementation In Malaysia: A Preliminary Overview. Journal of Information System and Technology Management, 6 (24), 7989.

\section{DOI: $10.35631 / J I S T M .624008$}

This work is licensed under CC BY 4.0

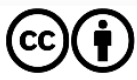

\begin{abstract}
:
The purpose of this study is to review the development of Smart Living for Smart City in Malaysia. Smart Living is an innovative concept of residential inspired through Smart City that complies with Sustainable Development Goals (SDGs) by accomodating human well-being and environmental concerns. However, there have been inconsistencies in terms of definition and features practised for the local context. Hence, this research seeks to determine the practical definition and standard of Smart Living by referring to Singapore, Finland, Thailand, and Ho Chi Minh. A preliminary literature review analysis will be conducted to outline a comprehensive analysis. The outcome should be able to identify the direction of Smart Living development to be applied in Malaysia by reviewing the priority, adoption practice, available features, and special initiatives from those countries to demonstrate the essence of the study. The finding will form a basis of criteria for further development of Smart Living locally and to assist construction industry players for mutual consensus on the definition and standard of Smart Living. This is crucial to further determine the development cost concerning Smart Living development later.
\end{abstract}

Keywords:

Smart City, Smart Living, Sustainable Development

\section{Introduction - Sustainability}

The first Sustainable meeting was held in 1972 through the United Nations Conference where world leaders were gathered to discuss human impacts on the environment, inspire world preservation and spread awareness upon individual responsibility (The United Nations 
Conference on the Human Environment, 1989). As Hardin (1990) wrote through 'The Tragedy of the Commons', individuals selfish pursuit of self-interest that was neglecting the well-being of overall society. Picking up from there, the United Nations strives towards making the world free from catastrophe, inclusive growth with transparency, dignity and equity. The sustainable movement covers social, environmental and economic aspects and acted upon through actions by decades. The current decade of actions - United Nations' 2030 which comprises 17 Sustainable Development Goals (SDGs).

Table 1: 17 Sustainable Development Goals (SDGs)

\begin{tabular}{|c|c|}
\hline Goal 1 - No Poverty & Goal 10 - Reduced Inequality \\
\hline Goal 2 - Zero Hunger & $\begin{array}{l}\text { Goal 11 }- \text { Sustainable Cities and } \\
\text { Community }\end{array}$ \\
\hline Goal 3 - Goof Health and Well-being & $\begin{array}{l}\text { Goal } 12 \text { - Responsible Consumption and } \\
\text { Production }\end{array}$ \\
\hline Goal 4 - Quality Education & Goal 13 - Climate Action \\
\hline Goal 5 - Gender Equality & Goal 14 - Life below Water \\
\hline Goal 6 - Clean Water and Sanitation & Goal 15 - Life on Land \\
\hline Goal 7 - Affordable and Clean Energy & $\begin{array}{l}\text { Goal 16 - Peace and Justice Strong } \\
\text { Institution }\end{array}$ \\
\hline $\begin{array}{l}\text { Goal } 8 \text { - Decent Work and Economic } \\
\text { Growth }\end{array}$ & Goal 17 - Partnership to achieve the Goal \\
\hline $\begin{array}{l}\text { Goal } 9-\text { Industry, Innovation and } \\
\text { Infrastructure }\end{array}$ & \\
\hline
\end{tabular}

Source: United Nations (2021)

From the list of goals, Goal $11^{\text {th }}$ - Sustainable Cities and Communities, is where the merging of Sustainability in the Construction Industry is. The main product of this industry - shelter, had been listed as a fundamental need for humans (Denton, 1990). However, in response to ecological, social and economic damage, the nature of shelter shifts from just accommodating towards treating. As it is also one of the efforts to achieve equilibrium in terms of well-being and environmental concerns amidst modernization.

\section{Literature Review}

\section{Overview on Smart Development}

Four points will be discussed in this section, starting with the concept of Smart in general then narrowing down into the concept of Smart Living. Follow up with the challenges and issues with Smart Living practices and the Smart Living implementation in Malaysia.

\section{Concept of Smart City in General}

The concepts of Smart City take into consideration of social, economic and environmental mutual benefits to draft comprehensive development plans and policies. As stated by EasyPark in their Smart City Index 2019 report, “digitalization doesn't just upgrade cities, it improves the quality of lives". Therefore, there are several definitions had been developed over time by different bodies to accommodate and drive the direction of Smart Development. 


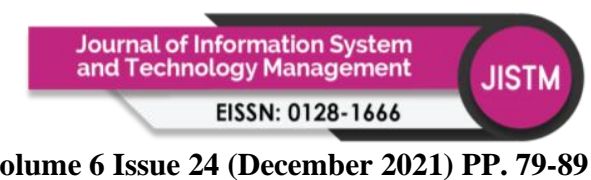

Volume 6 Issue 24 (December 2021) PP. 79-89 DOI: 10.35631/JISTM.624008

In a report titled back in 2018 titled "Top 50 Smart Cities Government" by Eden Strategy Institute and Ong \& Ong Pte Lte, the common practices done by those governments involve introducing smart initiatives funding, prepare comprehensive development strategies, identify smart clusters and innovation districts with intense digital inclusion, Open Data, co-creating among countries who has the same visions, establishing leadership models, active knowledge sharing, promoting smart workforce and always work towards and beyond affordability with efficiency.

\section{Smart Living}

Giffinger \& Gudrun (2010) and Cohen (2012) conclusively developed six (6) main components of Smart City that have been widely referred to as the fundamental for any Smart City development plans. The six (6) components are Smart Government, Smart Economy, Smart Environment, Smart Living, Smart Mobility, and Smart People. Smart Living is apart from the whole township development. Smart Living focuses are on catering to residences' needs and assist in terms of well-being.

Theoretically, there are multiple ways of defining the Smart Living concept. Firstly, it is defined as an environment that is made to fit the inhabitants' preference and requirements by being enriched with sensing, actuation, interaction (verbal or non-verbal) and computation capabilities to help occupants reach their convenient independence (Cicirelli et al., 2016; Sanchez, Pfeiffer, \& Skeie, 2017; Kadam, Mahamuni, \& Parikh, 2015). On the other hand, Madakam \& Ramaswamy (2016) perceived Smart Living is made up of two things - Smart appliances and Smart homes. Smart appliances are the connection of gadgets in technological ways to the Smart home and the Smart homes are the sole ability of the residential unit to monitor or adjust environmental systems, like a house that has a brain. On the contrary, Giffinger \& Gudrun (2010) perceived Smart Living concept houses as a form of cultural facilities that take into consideration of social cohesion in one neighbourhood, occupants' health conditions, individual safety, housing quality and also form a part of educational facilities. The last approach of definition is beyond just technology.

\section{Challenges and Issues with Smart Living Practice}

Throughout collective literature reviews from developed countries, there are several speculations and factors that contributed to the slow growth of Smart City which directly impacts the Smart Living development. Firstly, the whole development plan is claimed to be a rerun of traditional capitalism that incur market monopoly in term of technology by introducing unnecessary changes that prioritize Information Communication Technology (ICT) over the supply of basic needs. In other words, the whole development concern is mainly technologydriven rather than problem-driven (Cugurullo, 2018; Husár et al., 2017; Datta, 2016, Vidiasova, Kachurina, \& Cronemberger, 2017; Rosati \& Conti, 2016).

Besides, failures to share mutual ground between private and public sectors for comprehensive project development adds up to the issue of market monopoly. This implies the false adoption of a procurement system that does not match the position for a 'level playing field' therefore incurred a scenario of overpricing Smart Living projects (Husár et al., 2017; Viitanen \& Kingston, 2014).

Thirdly, plenty of feedbacks from private construction sectors about the implications of comparatively high capital cost (Ghosal \& Halder, 2018; Graham, Pranger, \& Azizi, 2015; 


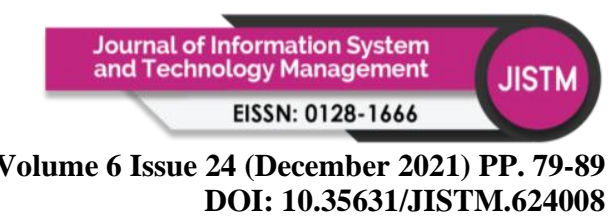

Simpson, 2018; Kamaruddin, Adul Hamid, \& Rohaizam, 2020; Macomber, 2018; Alusi, Eccles, Edmondson, \& Zuzul, 2011; Xiong, 2018) for Smart concept projects to conventional developments have affected their profit margin. This is due to the need to comply with the Smart requirements before being awarded the 'Smart' title. Thus, it requires them to narrow down their profit margin while maintaining the selling price range for their target markets. As the matter of fact, the third factor is the most concerning and are reflected by the scenario of mass housing market overhang that is reported to be due to the mismatch of housing price with their target markets.

\section{Smart Living in Malaysia}

Smart Living is undeniably new amidst dense conventional housing development in Malaysia. The innovation of merging sustainable and housing construction requires changes that cost a fortune because there is various facet in the industry ranging from individual, organizational to industry level (Zainudin et al., 2012). On top of that, there are issues regarding procuring the sustainable materials and technology of Smart features. The uncertain nature of Smart Living enables the developers to profit over features that are just fancy equipment without really serve the purpose of 'Smart' (Kamaruddin, Adul Hamid, \& Rohaizam, 2020). According to Kamaruddin, Adul Hamid, \& Rohaizam (2020), the latest discovery for their situational study in Johor, the 'must-have' Smart features provided by local developers remain at Landscaping, ICT Infrastructures and CCTV systems only.

Thus, this paper seeks to identify the practical Smart Living standard for Malaysia thus an overview will be conducted with the available literature. This is to review Smart Living practice from the top two (2) Smart Cities in Developed Countries and the top two (2) Smart Cities in South East Asia as ranked by IMD World Competitiveness Center, IMD Business School, Singapore University of Technology and Design \& SCO Smart City Observatory (2020).

Table 2: Ranking of Smart City in 2020

\begin{tabular}{llllll}
\hline & Developed Countries & \multicolumn{4}{c}{ South-East Asia Countries } \\
\hline Cities & Countries & Rank & Cities & Countries & Rank \\
Singapore & Singapore & $1 / 109$ & Singapore & Singapore & $1 / 109$ \\
Helsinki & Finland & $2 / 109$ & Kuala Lumpur & Malaysia & $54 / 109$ \\
Zurich & Switzerland & $3 / 109$ & Bangkok & Thailand & $71 / 109$ \\
Auckland & New Zealand & $4 / 109$ & Ho Chi Min & Vietnam & $83 / 109$ \\
Oslo & Norway & $5 / 109$ & Hanoi & Vietnam & $84 / 109$ \\
\hline
\end{tabular}

Source: IMD World Competitiveness Center, IMD Business School, Singapore University of Technology and Design \& SCO Smart City Observatory (2020)

\section{Findings - Smart Living in Developed Countries and South-East Asian Countries}

\section{Singapore}

According to Singapore Government Agency, their Smart Living concerns are towards achieving greater convenience, utility savings, as well as ensure peace of mind for families with elderly family members. The adoption of Smart Living priorities towards units produced by Singapore Housing and Development Board (HDB) houses or in Malaysia is known as affordable subsidized houses because there are up to $80 \%$ of Singaporeans stay in HDB units. 


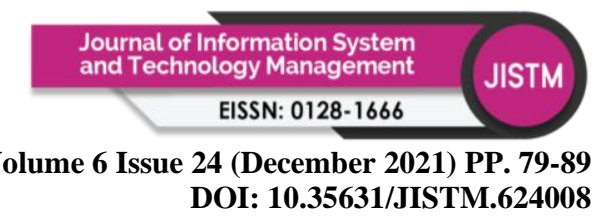

Through the HDB Smart Enabled Home Initiative, the smart components offered are firstly elderly monitoring system, secondly home energy management system and thirdly home water or waste management system. Features for the elderly monitoring system will be interactive sensors like a panic button, door contact sensor and motion sensor. While for home energy management system will be smart lighting with anticipatory software for optimizing provision of lights and solar panels under the name of SolarNova program for deployment of solar photovoltaic (PV) systems in Singapore, to promote and aggregate demand for solar PV across government agencies to achieve economies of scale, as well as drive the growth of Singapore's solar industry. Lastly, for the home water \& waste management system, the government proposed Pneumatic Waste Conveyance System. It is an automated waste collection system that uses a vacuum-type underground pipe network to collect household waste, which is then transported through underground pipes to a sealed container. Trucks then periodically collect the waste for disposal.

Table 3: Smart Living Practice in Singapore

\begin{tabular}{ll}
\hline Priority & \multicolumn{1}{c}{ Singapore } \\
Adoption Practice & Apply Smart Living affordable and elderly care \\
Initiative & HDB Smart Enabled Home Initiative \\
Features & $\begin{array}{l}\text { Interactive sensors; Home energy management; Water and waste } \\
\text { management }\end{array}$ \\
\hline
\end{tabular}

Source: Singapore Government Agency (n.d.)

\section{Helsinki, Finland}

Helsinki is continuously at the top of comparisons and evaluations of the European and global smart cities. Helsinki is launching three new projects as part of its Re-thinking Urban Housing program, which will result in 274 housing units. The program aims to improve the quality and appeal of flats as housing through customized solutions and collaboration. The construction of the rapidly growing city rests on an increasingly dense urban structure and 86 per cent of housing units in Helsinki are located in blocks of flats. For developers, the Rethinking program aims to provide an opportunity to try new things and receive valuable guidance from municipal experts. For residents, the program creates new housing alternatives and examples of how to improve the quality of flat housing.

The Excess Plus-Energy House project in the Kalasatama neighbourhood's - Työpajanpiha, is set to be realized through the Hitas system for owner-occupied flats. The four-year project involves 21 parties from eight countries and is funded by the EU Horizon 2020 program for research and innovation. It aims to prove the feasibility of transitioning from low-energy houses to Plus-Energy Houses, a building that on an annual basis generates more energy than it uses. The other two Re-thinking Urban Housing projects make use of a loan with a 20-year guarantee provided by the Housing Finance and Development Centre of Finland (ARA). These houses are going to be outfitted with smart home solutions, smart meters and renewable energy sources, such as e-mobility charging networks. 
Table 4: Smart Living Practice in Helsinki

\begin{tabular}{ll}
\hline \multicolumn{1}{c}{ Helsinki, Finland } \\
\hline Priority & \multicolumn{1}{c}{ Making Smart Living affordable } \\
Adoption Practice & $\begin{array}{l}\text { Apply smart features on residential units occupied by the majority } \\
\text { Re-thinking Urban Housing program, Excess Plus-Energy House } \\
\text { project }\end{array}$ \\
Features & $\begin{array}{l}\text { Smart home solutions - smart meters; Renewable energy sources - e- } \\
\text { mobility charging networks }\end{array}$ \\
\hline
\end{tabular}

Source: Hämäläinen (2020); Weekes (2019)

\section{Bangkok, Thailand}

The smart home trend in Thailand put extra effort into easing the burden of the elderly since they found out growing numbers of the elderly population have a higher dependency rate (Visutsak \& Daoudi, 2017). The ageing society has been a concern for the government of Thailand to prepare for policies regarding healthcare projects where one of the efforts is investing in an elderly assisted system - Smart Home.

The concept of assistive technology has been developed to facilitate self-care and enhance the independence of the elderly living in their homes. Some examples of assistive technology include devices that compensate services for cognitive, sensory, and physical disabilities; adoptions to the design, lighting, and furnishing of living environments; sensors and network systems that monitor daily activities to help the elderly maintain their health and safety while living independently; and various methods of social communication.

These features are: video monitoring as an activity monitoring system is used to monitor activities in daily life; fall detection for the exchange of signals between Bluetooth beacons attached in several places in the house and wearable devices can be used to detect falls; then the use of robotics like an intelligence cooking hob, oven and robot vacuum cleaners; shade and climate control for the fine-tuning control of shading related to home temperature, humidity, lighting, and ventilation; lighting control with the automatic lighting system allows any lights to be activated on and off when the elderly is in the room; Smartwatch as a wearable device for medical monitoring and fall detection; lastly video door entry systems.

Table 5: Smart Living Practice in Bangkok

\begin{tabular}{ll}
\hline \multicolumn{1}{c}{ Bangkok, Thailand } \\
\hline Priority & Elderly care \\
Adoption Practice & Apply assistive technology on residential units \\
Initiative & Health-care Program \\
& $\begin{array}{l}\text { Video monitoring; Fall detection for the exchange of signals between } \\
\text { Features }\end{array}$ \\
& $\begin{array}{l}\text { Bluetooth beacons; Robotic - intelligence cooking hob, oven and } \\
\text { robot vacuum cleaners; Shade and climate control; Lighting control; } \\
\text { Smartwatch for medical monitoring; video door entry systems }\end{array}$ \\
\hline
\end{tabular}

Source: Pal, Papasratorn, Chutimaskul, \& Funilkul (2019); Visutsak \& Daoudi (2017); Leeraphong, Papasratorn, \& Chongsuphajaisiddhi (2015)

\section{Ho Chi Minh, Vietnam}

According to the General Statistic Office of Vietnam, the total number of smart homes in 2020 is about 0.6 million. This number is relatively small compared to the total number of households in the nation. Moreover, as stated by one of their developers, most smart homes are 


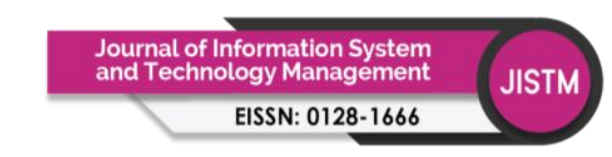

Volume 6 Issue 24 (December 2021) PP. $79-89$ DOI: 10.35631/JISTM.624008

developed in the residential sector of newly built or still under construction projects located mainly in the two most urbanized cities of Vietnam - Hanoi and Ho Chi Minh City. However, installing smart technologies would result in a higher price tag for the properties, which would likely limit the target market to the high-end segment. This consequently explains one of the reasons why it was slow in the first phase to penetrate the smart home market in Vietnam.

Nonetheless, the potential for market growth is still high as many developers have become more proactive in integrating the concept of smart home in their projects and offering smart techs as extras in a promotion or free experience program. Particularly, when looking at the six key segments of smart home application, even though not accounting for the highest in terms of revenue as stated above, "control and connectivity", "home entertainment" and "comfort \& lightning" are the most application for smart homes in Vietnam.

It can be deduced that the ability to "control and connect" as well as entertainment and comfortless factors are the focal points of the smart home concept which is supposed to bring the most added values the daily life in Vietnam. In addition, integrated devices that can connect to another device will dominate the stand-alone devices because of their usability and functional diversity. Most of the households equipped with smart appliances will be high-end apartments with modern electrical systems.

Table 6: Smart Living Practice in Ho Chi Minh

\begin{tabular}{ll}
\hline \multicolumn{1}{c}{ Ho Chi Minh, Vietnam } \\
\hline Priority & Launching new high-end residential projects \\
Adoption Practice & $\begin{array}{l}\text { Apply assistive technology on residential units, new high-end } \\
\text { projects }\end{array}$ \\
Initiative & No special initiative \\
Features & Control and connectivity; Home entertainment; Comfort \& lightning \\
\hline
\end{tabular}

Source: Hong Loan \& Van Tin (2018)

\section{Suggestion on Smart Living Adoption in Malaysia}

There is a similarity between Singapore and Helsinki whereas the focus of developing Smart Living is towards affordable housing. It involves building new projects and also improvising ready units simultaneously. On the other hand, in Bangkok and Vietnam, the private institutions work vigorously with their governments to produce new residential projects that instil the value and quality of smart. One of the possible reasons for the differences between the two distinct practices in respective countries status and populations. As generally known, developed nations are measured by having high gross domestic product (GDP) gross national product (GNP), the per capita income, level of industrialization, amount of widespread infrastructure and general standard of living (Majaski, 2020). While developing countries are typically an agriculturalbased country that is seeking to become more advanced economically and socially (Kwa, 2001). This implies developed nations have sufficient residential units while developing countries still require more to cater for their populations. Besides, it is a matter of affordability and target markets for respective countries.

However, all these countries share almost the same goals in the work on producing Smart Home - elderly care. Elderly care is described as the priority concern which aligned with the definition of Smart Living in the first place, which is to help occupants reach their convenient independence throughout their daily routines (Cicirelli et al., 2016; Sanchez, Pfeiffer, \& Skeie, 2017; Kadam, Mahamuni, \& Parikh, 2015). The concerns towards the ageing population should Copyright (C) GLOBAL ACADEMIC EXCELLENCE (M) SDN BHD - All rights reserved 


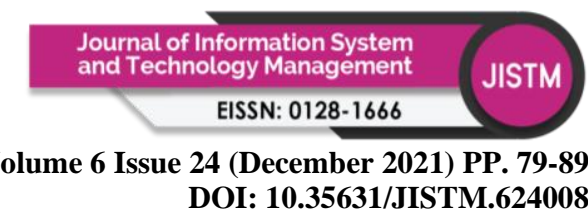

be taken seriously and perhaps formed a part of their healthcare initiatives as it is a part of human well-being as emphasizing in Sustainability Development. Well-being had been recognized as a complicated and multifaceted process where it takes different forms across time, settings and societies demanding for an all-inclusive environment for human settlement (Bakar, Osman, Bachok, Ibrahim, \& Mohamed, 2015). Clear (2018) mentioned this is important for better productivity and value creation. All in all, for the local context, the wellbeing of Malaysian should come as the priority in developing Smart Living.

Therefore, by considering Malaysia economy, populations and cultural backgrounds and the ideas contributed by those four countries, the initiatives for Smart Living development shall be made accessible. People have to be reminded that Smart Living is made for well-being. Prolong asymmetric information about quality standards or requirements that are not mandatorily imposed onto the industry will enable the opportunistic behaviour of market players and may lead them to continue producing conventional houses (Akerlof, 1970).

Besides, Smart Living shall be made available for the majority like the practice by Singapore and Helsinki where they focus on retrofitting the HBR units and flats that are both affordable houses for their medium to low incomes citizens. In Malaysia context, the medium to low incomes communities are categorized as the M40 and B40 groups. In fact, these are the people who require the most assistance in their lives especially in regards to health, well-being and convenience. Perhaps, layers of Smart Living implementation are needed to accommodate various community needs. Further clarification about the type of Smart Living features to be adopted should be precisely defined and standardised with in-depth research within the Malaysia market so that the supply meets the market need practically.

\section{Conclusion}

This paper provides a preliminary review of the idea of Smart Living practice in developed countries (Singapore and Finland) and developing countries (Thailand and Vietnam) with the milestone reached in Malaysia. The constraint for execution is the undefined standards that are forming a gap of practice. Thus, the choices of features implementation and an optimum development procedural for Smart Living should be standardised according to local necessities, complimentary needs and desired opportunities in Malaysia.

\section{References}

Akerlof, G. A. (1970). The market for "lemons": Quality uncertainty and the market mechanism. Quarterly Journal of Economics, 84(3), 488-500. https://doi.org/10.2307/1879431

Alusi, A., Eccles, R. G., Edmondson, A. C., \& Zuzul, T. (2011). Sustainable Cities: Oxymoron or the Shape of the Future? In SSRN Electronic Journal. https://doi.org/10.2139/ssrn.1726484

Bakar, A. A., Osman, M. M., Bachok, S., Ibrahim, M., \& Mohamed, M. Z. (2015). Modelling Economic Wellbeing and Social Wellbeing for Sustainability: A Theoretical Concept. Procedia Environmental Sciences, 28(February 2020), 286-296. https://doi.org/10.1016/j.proenv.2015.07.037

Cicirelli, F., Fortino, G., Giordano, A., Guerrieri, A., Spezzano, G., \& Vinci, A. (2016). On the Design of Smart Homes: A Framework for Activity Recognition in Home Environment. Journal of Medical Systems. https://doi.org/10.1007/s10916-016-0549-7

Clear, J. (2018). Atomic Habics. Londom, United Kingdom: Cornerstone. 


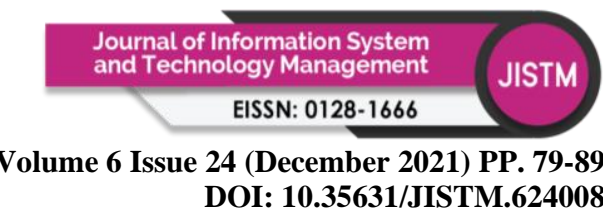

Cohen, B. (2012). What exactly is a Smart city? Retrieved December 7, 2020, from Fast Company website: https://www.fastcompany.com/1680538/what-exactly-is-a-smartcity

Cugurullo, F. (2018). The Origin of the Smart City Imaginary: From the Dawn of Modernity to the Eclipse of Reason. In The Routledge Companion to Urban Imaginaries. https://doi.org/10.4324/9781315163956

Datta, A. (2016). Three Big Challenges for Smart Cities and How to Solve Them. Retrieved December 7, 2020, from The Conversation website: https://theconversation.com/threebig-challenges-for-smart-cities-and-how-to-solve-them-59191

Denton, J. (1990). Society and the Official World: A Reintroduction to Sociology. Dix Hill, New York: General Hall.

EasyPark. (2019). Smart City Index 2019. Retrieved December 20, 2020, from https://www.easyparkgroup.com/smart-cities-index/\#: :text="The Smart Cities Index 2019,\%2C of course\%2C smart parking.

Eden Strategy Institute and Ong \& Ong Pte Ltd. (2018). Top 50 Smart City Governments. Retrieved from https://static1.squarespace.com/static/5b3c517fec4eb767a04e73ff/t/5b513c57aa4a99f 62d168e60/1532050650562/Eden-OXD_Top+50+Smart+City+Governments.pdf

Ghosal, A., \& Halder, S. (2018). Building Intelligent Systems for Smart Cities: Issues, Challenges and Approaches. 107-125. https://doi.org/10.1007/978-3-319-76669-0_5

Giffinger, R., \& Gudrun, H. (2010). Smart Cities Ranking: An Effective Instrument for the Positioning of the Cities? Journal of the Centre of Land Policy and Valuation, 4(12), 7-25. Retrieved from http://wwwcpsv.upc.es/ace/Articles_n10/Articles_pdf/ACE_12_SA_10.pdf

Graham, M., Pranger, J., \& Azizi, A. (2015). Smart Cities in Southeast Asia: The Opportunity for Telcos. Price Waterhouse Cooper, 20. Retrieved from https://www.pwc.com/my/en/publications/smart-cities-in-sea-2015.html

Hämäläinen, M. (2020). A Framework for a Smart City Design: Digital Transformation in the Helsinki Smart City. Contributions to Management Science, (September 2019), 63-86. https://doi.org/10.1007/978-3-030-23604-5_5

Hardin, G. (1990). The Tragedy of the Commons. The Social Contract, 1(1). Retrieved from https://www.thesocialcontract.com/artman2/publish/tsc0101/article_6.shtml

Hong Loan, N., \& Van Tin, N. (2018). Design of high-rise dwelling houses for Ho Chi Minh City within the framework of the "smart city" concept. E3S Web of Conferences, 33. https://doi.org/10.1051/e3sconf/20183301026

Husár, M., Ondrejička, V., \& Variş, S. C. (2017). Smart Cities and the Idea of Smartness in Urban Development - A Critical Review. IOP Conference Series: Materials Science and Engineering, 245(8). https://doi.org/10.1088/1757-899X/245/8/082008

IMD World Competitiveness Center, IMD Business School, Singapore University of Technology and Design, \& SCO Smart City Observatory. (2020). Smart City Index 2020. Retrieved from https://www.esmartcity.es/biblioteca/imd-smart-city-index-2020

Kadam, R., Mahamuni, P., \& Parikh, Y. (2015). Smart Home System. 2(1), 81-86.

Kamaruddin, T., Adul Hamid, R., \& Rohaizam, N. A. S. (2020). A Situational Study on Sustainable Housing Features in Johor. IOP Conference Series: Materials Science and Engineering, 849(1). https://doi.org/10.1088/1757-899X/849/1/012037

Kwa, A. (2001). Agriculture in Developing Countries : Which Way Forward? Trade-Related Agenda, Development and Equity, 4, 1-22. 


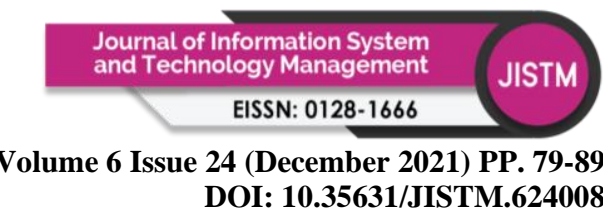

Leeraphong, A., Papasratorn, B., \& Chongsuphajaisiddhi, V. (2015). A Study on Factors Influencing Elderly Intention to Use Smart Home in Thailand : A Pilot Study. The 10th International Conference on E-Business, 1-10. Retrieved from http://www.inceb2015.sit.kmutt.ac.th/paper/P24AtcharaNew.pdf

Macomber, J. (2018). Smart Cities are Complicated and Costly: Here's How to Build Them. Retrieved from Harvard Business Publishing website: https://hbswk.hbs.edu/item/smart-cities-are-complicated-and-expensive-here-s-howto-build-them

Madakam, S., \& Ramaswamy, P. R. (2016). Smart Cities - Six Dimensions. Conference on Advances in Computing and Information Technology, (January 2014). https://doi.org/10.3850/978-981-07-8859-9

Majaski, C. (2020). Developed Economy. Investopedia. Retrieved from https://www.investopedia.com/terms/d/developed-economy.asp

Pal, D., Papasratorn, B., Chutimaskul, W., \& Funilkul, S. (2019). Embracing the Smart-Home Revolution in Asia by the Elderly: An End-User Negative Perception Modeling. IEEE Access, 7(April), 38535-38549. https://doi.org/10.1109/ACCESS.2019.2906346

Rosati, U., \& Conti, S. (2016). What is a Smart City Project? An Urban Model or A Corporate Business Plan? Procedia - Social and Behavioral Sciences, 223, 968-973. https://doi.org/10.1016/j.sbspro.2016.05.332

Sanchez, V. G., Pfeiffer, C. F., \& Skeie, N. O. (2017). A review of smart house analysis methods for assisting older people living alone. Journal of Sensor and Actuator Networks, 6(3), 1-38. https://doi.org/10.3390/jsan6030011

Simpson, P. (2018). Smart Cities: Understanding the Challenges and Opportunities. In Smart City World. Retrieved from https://smartcitiesworld.net/AcuCustom/Sitename/DAM/012/Understanding_the_Chal lenges_and_Opportunities_of_Smart_Citi.pdf

Singapore Government Agency. (n.d.). Smart Towns - Home. Retrieved April 21, 2021, from http://smarttowns.rhpl.org/\%0Ainternal-pdf://0.0.7.164/smarttowns.rhpl.org.html

The United Nations Conference on the Human Environment. (1989). Declaration of the United Nations Conference on the Human Environment, 1972. In Indian Journal of Public Administration (Vol. 35). https://doi.org/10.1177/0019556119890340

United Nations. (2021). The Sustainable Development Goals Report 2021. In The sustainable development goals report. https://doi.org/10.29171/azu_acku_pamphlet_k3240_s878_2016

Vidiasova, L., Kachurina, P., \& Cronemberger, F. (2017). Smart Cities Prospects from the Results of the World Practice Expert Benchmarking. Procedia Computer Science, 119(2017), 269-277. https://doi.org/10.1016/j.procs.2017.11.185

Viitanen, J., \& Kingston, R. (2014). Smart cities and green growth: Outsourcing democratic and environmental resilience to the global technology sector. Environment and Planning A, 46(4), 803-819. https://doi.org/10.1068/a46242

Visutsak, P., \& Daoudi, M. (2017). The smart home for the elderly: Perceptions, technologies and psychological accessibilities: The requirements analysis for the elderly in Thailand. ICAT 2017 - 26th International Conference on Information, Communication and Automation Technologies, Proceedings, 2017-Decem(October), 1-6. https://doi.org/10.1109/ICAT.2017.8171625

Weekes, S. (2019). Helsinki launches three new projects to 'Rethink Urban Housing '. Retrieved April 15, 2021, from Smart Cities World website: 
Volume 6 Issue 24 (December 2021) PP. 79-89 DOI: 10.35631/JISTM.624008

https://www.smartcitiesworld.net/news/news/helsinki-launches-three-new-projects-torethink-urban-housing-4870

Xiong, X. (2018). Cost-Benefit Analysis of Smart Cities Technologies and Applications (University Delaware).

Retrieved

from https://udspace.udel.edu/handle/19716/23818

Zainudin, A. Z., Latiff, M. A., Yunus, N. M., Yusof, N., Rahman, M. M. G. M. A., \& Hussin, K. (2012). Housing Developers' Initiatives in Supporting Sustainable Housing Development in Iskandar Malaysia. International Journal of Real Estate Studies, 7(1). 